\title{
Designing and Fabrication of Electrochromic Windows Using Tungsten Oxide Films Prepared Through Sol-gel Coating on a Glass
}

\author{
Nayyereh Daroogheh, Elham Karimi, and Seyed Mohammad Bagher Ghorashi* \\ Department of Physics, Faculty of Physics, University of Kashan, Kashan, Iran \\ *Corresponding Author's Email: mghorashi@kashanu.ac.ir
}

Received: Mar. 6, 2018, Revised: May. 29, 2018, Accepted: Sep. 4, 2018, Available Online: Dec. 27, 2019

DOI: 10.29252/ijop.13.2.79

\begin{abstract}
In this study, a sol-gel peroxotungstic acid sol was employed to deposit tungsten oxide $\left(\mathrm{WO}_{3}\right)$ films by the spin-coating technique. In view of smart window applications, electrochromic windows were then designed and fabricated using a thin tungsten oxide film. For this purpose, Glass/ $\mathrm{FTO} / \mathrm{WO}_{3} /$ electrolyte/ FTO/Glass could be of use due to its special structure that consists of an electrochromic layer $\left(\mathrm{WO}_{3}\right)$ on a transparent conductor (FTO), an electrolyte containing $\mathrm{Li}^{+}$ cations, and a transparent conductor layer. A voltage was applied on the fabricated sample, which was later assesed for its transmission, switching speed, and coloration efficiency. An increase in the coloration efficiency from 87 $\mathrm{cm}^{2} / \mathrm{C}^{-1}$ to $99.1 \mathrm{~cm}^{2} / \mathrm{C}^{-1}$ was found associated with an increase in the deposition speed. Moreover, the increase in the deposition speed led to a decrease in the coloration and bleaching time duration from $11.4 \mathrm{~s}$ to $6.2 \mathrm{~s}$ and from 12.8 $\mathrm{s}$ to $5.2 \mathrm{~s}$ respectively. The results obtained on the thin film $\mathrm{WO}_{3}$ can be useful for electrochromic applications.
\end{abstract}

KEYWORDS: Electrochromic material, Sol-gel preparation, Tungsten oxide, Coloration.

\section{I.INTRODUCTION}

The growth of the world population and the subsequent growth of demands for energy have brought an awareness of renewable energy resources. However, the uncontrollable and periodic nature of these energy resources has intensified the need for an efficient energy savers system. Electrochemical devices (ECDs), which are formed of EC materials, electrolytes and electrodes, can savers energy and/or convert it [1-3]. Since 1953, when Balzers presented a very clear description of electrochromism in tungsten oxide films or, since 1969, when Deb changed the situation of EC knowledge by his publications, more and more scientists have engaged in the research field of EC materials, and, as a result, more EC materials have been discovered and reported $[3,4]$. Electrochromic (EC) materials are able to reversibly and persistently change their optical properties at an external voltage. They are considered as one of the most promising candidates for energy-saving smart (ESS) windows [1]. The primary function of glass, particularly in architectural applications, is to transmit light. A smart-window glass would be one whose light transmission properties can be changed in response to an external stimulus such as light, heat, or electrical impulse [3,5]. Well-known examples are photochromic, thermochromic, and electrochromic glasses. Electrochromism is broadly defined as a reversible optical change in a material induced by an external voltage. Many inorganic and organic species show electrochromic properties throughout the electromagnetic spectrum [6-8]. Among them, smart windows have an important application because they can effectively save energy by regulating the solar heat gain and providing indoor comfort through reversible color changes. Many applications have been developed based on these unique properties. The properties have been applied in such things as electrochromic 
devices, polymeric batteries, photovoltaic cells, energy storage, optoelectronics, rearview mirrors for cars and vehicles, and display devices [9-11]. Among metal oxides, tungsten trioxide $\left(\mathrm{WO}_{3}\right)$ is a feasible electrochromic material that can be of benefit in practical applications due to its rather highly optical reversible color change induced by an electrochemical process. This process leads to the potential application of the material in smart windows, electrochromic windows, switchable devices, and optical-based gas sensors [12]. Over the past 30 years, a large body of research has been carried out to synthesize tungsten oxide films for electrochromic devices because the films exhibit a fairly good optical modulation and high cyclic stability $[13,14]$. The electrochromic phenomenon of tungsten oxide was originally discovered in tungsten oxide $\mathrm{WO}_{3}$ thin films. The material still remains as the most promising, the most studied, and the most applied electrochromic material for windows and devices. Electrochromism of tungsten oxide is a complex phenomenon, but it is not completely understood yet. As reported in the literature, insertion of ions and electrons in an amorphous $\mathrm{WO}_{3}$ film can switch it from its bleached state (transparent) to a colored state (dark blue) to form tungsten bronze according to the reaction given in Equation (1).

$$
\text { (Transparent) } W O_{3}+x M++x e-\leftrightarrow
$$

$M_{x} W O_{3}$ (Dark blue)

where $\mathrm{M}+$ can be $\mathrm{H}^{+}, \mathrm{Li}^{+}, \mathrm{Na}^{+}$or $\mathrm{K}^{+}, 0<\mathrm{x}<1$, and e- denotes electrons $[4,14]$. Initially transparent in the visible region, $\mathrm{WO}_{3}$ is converted to $\mathrm{M}_{\mathrm{x}} \mathrm{WO}_{3}$ ( $\mathrm{M}$ can be hydrogen or an alkali metal) through a cation intercalation (reduction) process, which leads to strong absorption bands in the visible region and makes it a cathodically coloring material $[15$, $16]$.

A variety of conventional deposition methods have been used to prepare $\mathrm{WO}_{3}$ films, such as direct current (DC), radio frequency (RF), magnetron sputtering, sol-gel methods, plasma spraying method, electron beam evaporation, thermal evaporation, and hydrothermal methods [17-19]. There is a strong dependence of electrochromic properties like coloration efficiency, electrochemical kinetics and cyclic durability on layer properties such as layer density and surface morphology. Accordingly, there is a direct relationship between growth techniques and deposition parameters [20,21]. In this study, however, sol-gel processing is most popular because of its cost-effectiveness, ease of deposition, and uniform large-area films for window application. More importantly, it allows tailor making of the microstructure of films by introducing chemical dopants into the reactant sols or by controlling the annealing conditions, which improves the properties of the films $[20,16]$. Sol-gel technology for deposition of thin films of electrochromic tungsten oxide has gained enough impetus over the past decade owing to its low cost and adaptability to large-area deposition. Describing the merits of sol-gel paves the way for deposition of electrochromic coatings of inorganic transition metal oxides, as the process is easy to scale and, consequently, amenable for coating substrates of even a one-square-meter area. Central to the success of commercially focused electrochromic products, such as smart windows, is the ability to reproducibly deposit electrochromic films that have a good cosmetic quality and a high coloration efficiency $[22,23]$. In the present study, $\mathrm{WO}_{3}$ films are prepared by the sol-gel technique and with respect to the structural, morphological, electrical and optical properties of $\mathrm{WO}_{3}[24$, 25].

\section{Novelty OF THE STUDY}

Owing to the wide industrial and commercial applications of electrochromic glasses and the increasing need for energy and appropriate ways of using it, the aim of this study was set to be fabrication of an electrochromic glass through a combination of sol-gel and spincoating techniques, which is the lowest-cost process. The manufactured cells proved to have a better function in terms of light transmission, response time, and dye 
efficiency. To the best of our knowledge, these cells are superior to many other ones developed by costly methods and vacuumbased procedures; therefore, they can be of benefits for industrial, commercial, and household purposes.

\section{III.EXPERIMENTS}

\section{A. Preparation of the sol}

Dissolution of 3 grams of a tungsten metal powder (Merck) in a mixture of $20 \mathrm{ml}$ of hydrogen peroxide $\left(\mathrm{H}_{2} \mathrm{O}_{2}\right.$; Qualigens, glaxo) and $2 \mathrm{ml}$ of deionized water yielded a colorless solution of peroxotungstic acid. The reaction being exothermic was conducted between $0^{\circ} \mathrm{C}$ and $10^{\circ} \mathrm{C}$. Then, a clear solution was obtained by filtration, and $20 \mathrm{ml}$ of glacial acetic acid (Merck) was added to it. The resulting solution was refluxed at $55^{\circ} \mathrm{C}$ for six hours. The white, dense and viscous solution thus obtained was then dried under vacuum at $55^{\circ} \mathrm{C}$ to recover a flaky pale yellow peroxotungstic acid product (APTA). The deposition solution was prepared by dissolving $1 \mathrm{~g}$ of APTA in $3 \mathrm{cc}$ of absolute alcohol (99.9\%, E-Merck). The dissolution rate was catalyzed by slight heating at about $55^{\circ} \mathrm{C}$

\section{B. Preparation of the films}

The coatings were deposited by the spincoating method (from the speed of $1500 \mathrm{rpm}$ to $3500 \mathrm{rpm}$ for 30 seconds). On an FTO $(1.5 \mathrm{~cm} \times 2 \mathrm{~cm})$, coated glass substrates $(8 \Omega / \mathrm{sq})$ had previously been cleaned and rinsed with distilled water, methanol, and aston and then dried at $90^{\circ} \mathrm{C}$. All the films were annealed from room temperature to $100^{\circ} \mathrm{C}$, held at this temperature for two hours, and then brought back to room temperature.

\section{Characterization techniques}

The X-ray diffraction (XRD) patterns of all the films were recorded in the $2 \theta$ range from $10{ }^{\circ} \mathrm{C}$ to $90^{\circ} \mathrm{C}$, and the wavelength of the $\mathrm{Cu} \mathrm{K \alpha}$ radiation was found to be $1.54 \mathrm{~A}^{\circ}$. The average grain/crystallite size was determined using Scherrer's formula as follows:
$D_{h k l}=\frac{K \lambda}{\Gamma_{h k l} \cos \theta_{h k l}} \frac{360}{2 \pi}$

where $\lambda$ is the wavelength of the incident beam, $\Gamma_{h k l}$ is the full width at half maximum (FWHM) of the peak, $\theta_{h k l}$ is the Bragg angle, and $K$ is a dimensionless constant [26,27]. AFM studies were used to calculate the particle size and the average roughness of the films. Transmittance variation and color changes were detected through a Uv-vis (Cintra6) spectrometer at a visible wavelength ranging from $350 \mathrm{~nm}$ to $1100 \mathrm{~nm}$. Optical modulation and switching studies were carried out in a two-electrode system for $\pm 3 \mathrm{~V}$. There exist few reports about inorganic ECDs based on two-electrode films. Therefore, all the electrochemical studies were carried out in an electrolyte of $1.0 \mathrm{M} \mathrm{\textrm {LiClO } _ { 4 }}$ in propylene carbonate (PC). Fig. 1 provides the configuration of the electrochemical device. In this electrochemical design, the window is an electrochemical cell in which two glass panels are separated by an electrolyte material. The $\mathrm{EC}$ device consists of a thin film of $\mathrm{EC}\left(\mathrm{WO}_{3}\right)$ material and a conductive ion layer (IC) between two layers of transparent conductive oxide (TCO). In the open-circuit voltage, the window is on. This means that both the working electrode and the counter electrode are transparent to the sun, allowing heat and natural light to enter the room [28]. Upon arriving in the voltage range from 1 to 3 volts, the window changes to darkness, limiting the amount of heat and natural light entering the room [29].

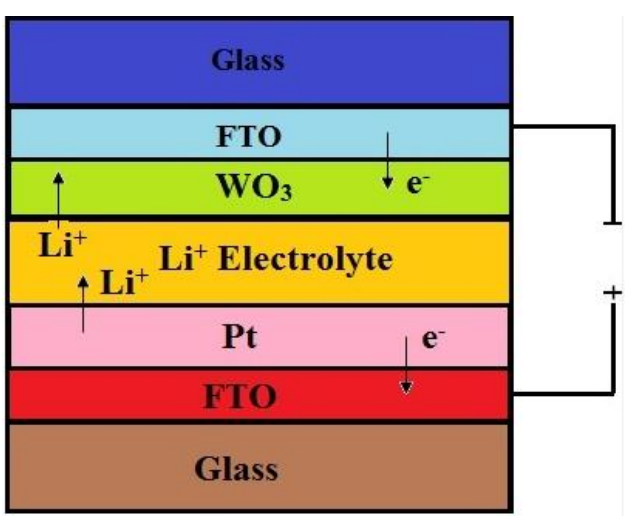

Fig. 1. Schematic display of the electrochromic device. 


\section{IV.RESULTS AND DISCUSSION}

\section{A. Results and discussion}

Figure. 2 shows the X-ray diffraction patterns of the annealed $\mathrm{WO}_{3}$ films as a function of temperature. Figures 2(a) and 2(b) show the XRD pattern of the $\mathrm{WO}_{3} / \mathrm{FTO} /$ Glass structure at the temperatures of $100^{\circ} \mathrm{C}$ and $250^{\circ} \mathrm{C}$ respectively. There are some peaks observed which stem from the FTO substrate. However, there are no peaks detected associated with the $\mathrm{WO}_{3}$ layer, indicating an amorphous $\mathrm{WO}_{3}$ film. In both films, a wide range is observed in the range from 20 to 30 degrees, which is a characteristic of their amorphous structure. Another finding, as reported in the literature as well, is the crystallization of $\mathrm{WO}_{3}$ films occurring at $500^{\circ} \mathrm{C}$ [30-32].

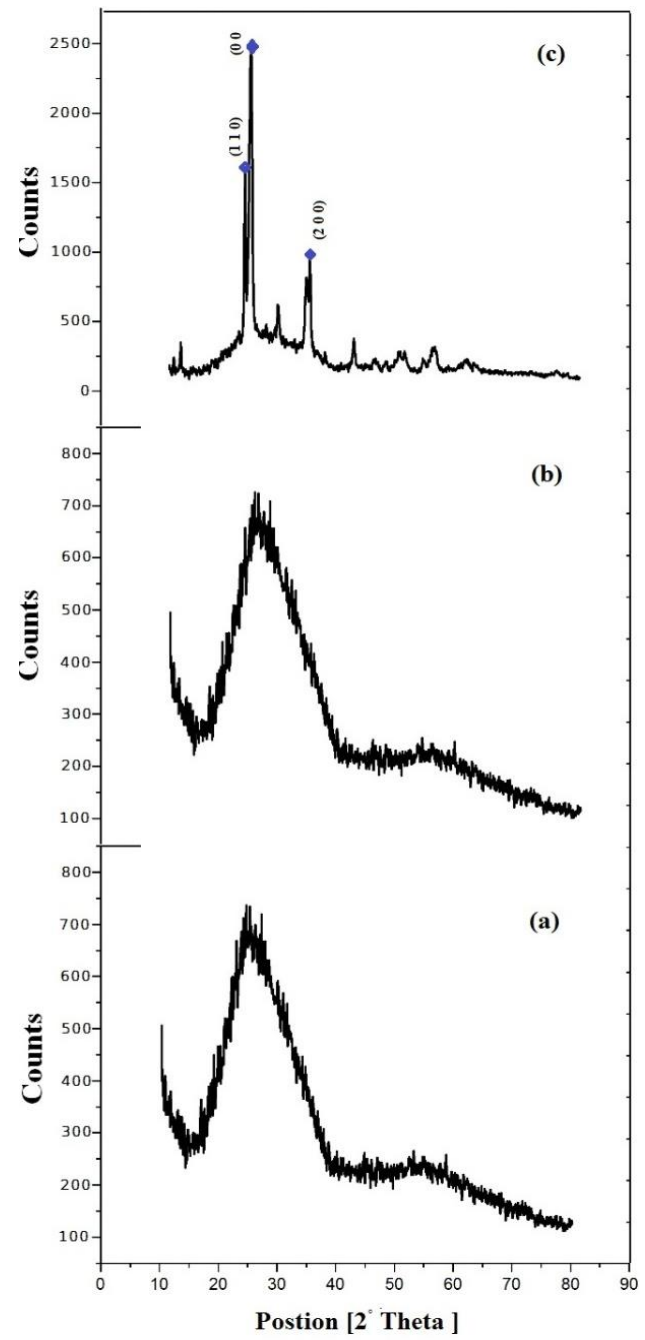

Fig. 2. XRD patterns of an as-deposited $\mathrm{WO}_{3}$ film and the films annealed at (a) $100^{\circ} \mathrm{C}$, (b) $250^{\circ} \mathrm{C}$, and (c) $500^{\circ} \mathrm{C}$ prepared by the spin-coating technique; the substrates have been $\mathrm{SnO}_{2}: \mathrm{F}$.
At this annealing temperature, a significant narrowing of Bragg's peaks is observed for all the films, which is consistent with the increase of the grain/crystallite size in the $\mathrm{WO}_{3}$ films. Figure $2 c$ displays the XRD pattern of the spin-coated film annealed at $500^{\circ} \mathrm{C}$. The pattern shows three dominant diffraction peaks at $\mathrm{d}=3.87 \mathrm{~A}^{\circ}(\mathrm{h} \mathrm{k} \mathrm{l}=0001), \mathrm{d}=3.71 \mathrm{~A}^{\circ}(\mathrm{h} \mathrm{k} \mathrm{l}=11$ 0 ) and $d=2.63 \mathrm{~A}^{\circ}$ (h k l=2 00 ). Using these values and Scherrer's formula, the grain size was estimated to be $5 \mathrm{~A}^{\circ}$. With regard to similar trends as reported in the literature, amorphous tungsten oxide films generally exhibit better electrochromic performance than their crystalline counterparts [33]. Thus, heat treatment is focused on $100^{\circ} \mathrm{C}$, at which amorphous and transparent tungsten oxide films can be obtained [34].

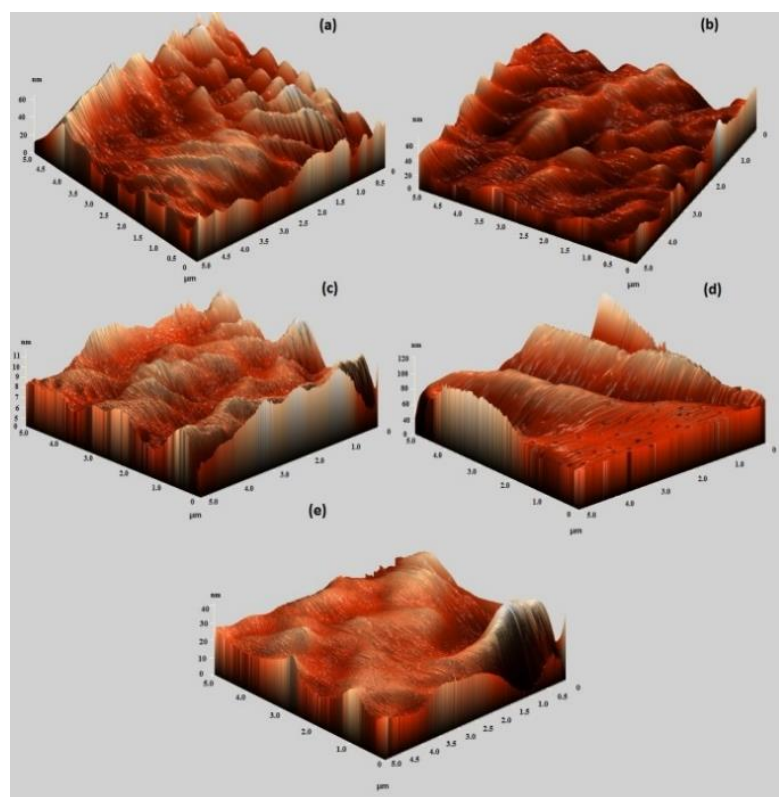

Fig. 3. AFM images of the $\mathrm{WO}_{3}$ thin films deposited at the speeds of (a) 1500 (b) 2000 (c) 2500 (d) 3000 and (e) $3500 \mathrm{rpm}$.

The surface topography of the films was studied using atomic force microscopy (AFM) in a tapping mode. Figures 3a-e show the atomic force microscopy (AFM) images of the $\mathrm{WO}_{3}$ thin films recorded in a $1 \mathrm{~mm} \times 1 \mathrm{~mm}$ area as a function of deposition speed. The root mean square (RMS) roughness values of the $\mathrm{WO}_{3}$ films are presented in Table 1. The RMS roughness calculated in a $1 \mathrm{~mm} \times 1 \mathrm{~mm}$ area, as shown in Table 1, is more than $3 \mathrm{~nm}$ for all the films deposited at a speed less than $3500 \mathrm{rpm}$, 
but it decreases to $2 \mathrm{~nm}$ at the speed of 3500 rpm. It is to be noted that the films are randomly set on the surface [30]. As it is observed, the particle size decreases with an increase in the deposition speed. It may be due to the agglomeration of the grains once the deposition speed increases. Also, as in Fig. 3, at the speed of $3500 \mathrm{rpm}$, the film surface morphologically seems to be almost the same as a smooth surface; it is an amorphous structure with nanometric grains.

Table 1. RMS roughness values calculated from a $1 \mathrm{~mm} \times 1 \mathrm{~mm}$ area

\begin{tabular}{|c|c|}
\hline \hline Deposition speed (rpm) & RMS (nm) \\
\hline \hline 1500 & 7.01522 \\
2000 & 8.87050 \\
2500 & 3.33174 \\
3000 & 17.9731 \\
3500 & 2.91146 \\
\hline \hline
\end{tabular}

The surface and the cross-sectional morphology features of the $\mathrm{WO}_{3}$ films deposited at the deposition speed of $3500 \mathrm{rpm}$ (i.e. best speed) are illustrated in Fig. 4. Those features suggest the crevice-free homogeneous structure of the films. All the films reveal a typical columnar and dense structure. Some cracks exist in their texture, which is due to the strain imposed on the layers during the heat treatment and the removal of water. Our study revealed that these cracks do not affect the electrochromic properties of the films.

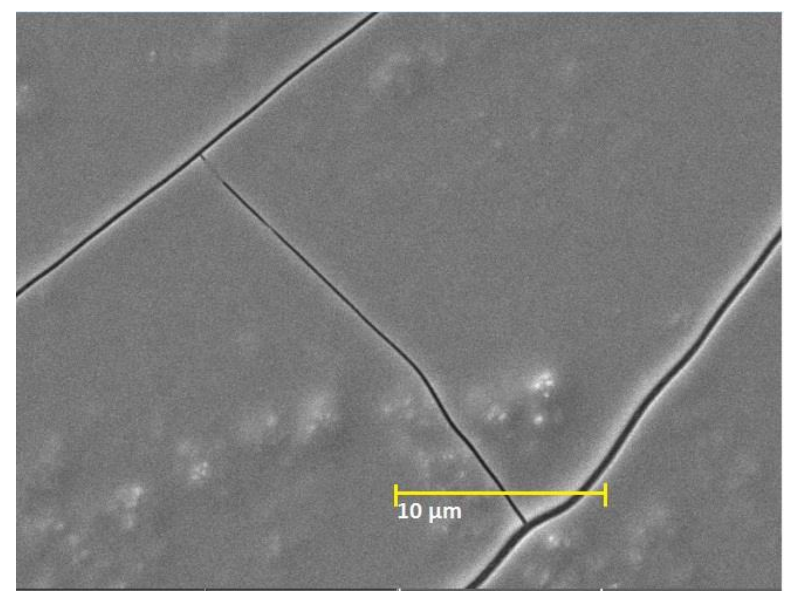

Fig. 4. SEM image of the $\mathrm{WO}_{3}$ thin film deposited at $3500 \mathrm{rpm}$ (best speed).

\section{B. Electrochromic properties}

The transmittance spectra within the wavelength range of $350 \leq \lambda \leq 1100 \mathrm{~nm}$ for the spin-coated films annealed at $100^{\circ} \mathrm{C}$, colored, and bleached are illustrated in Fig. 5. By applying various voltages ranging from $0 \mathrm{~V}$ to $1.0 \mathrm{~V}$, the $\mathrm{WO}_{3}$ films were colored from clear to dark blue. It was seen that the transmission would decrease sharply when the film was colored dark blue [35, 36]. In general, the transmittance of these films lies in the range of $\approx 50-36 \%$ in the visible region, but it decreases in a non-monotonic manner as a function of increasing wavelength in the NIR region. The transmittance modulation occurs at the wavelength of $650 \mathrm{~nm}$ (designated as $\Delta \mathrm{T} 650$ ) for a tungsten oxide film. It can be noted that tungsten oxide films at the of speed $3500 \mathrm{rpm}$ exhibit better electrochromic performance than their counterparts with $(\Delta \mathrm{T} 650=53 / 16 \%)$.
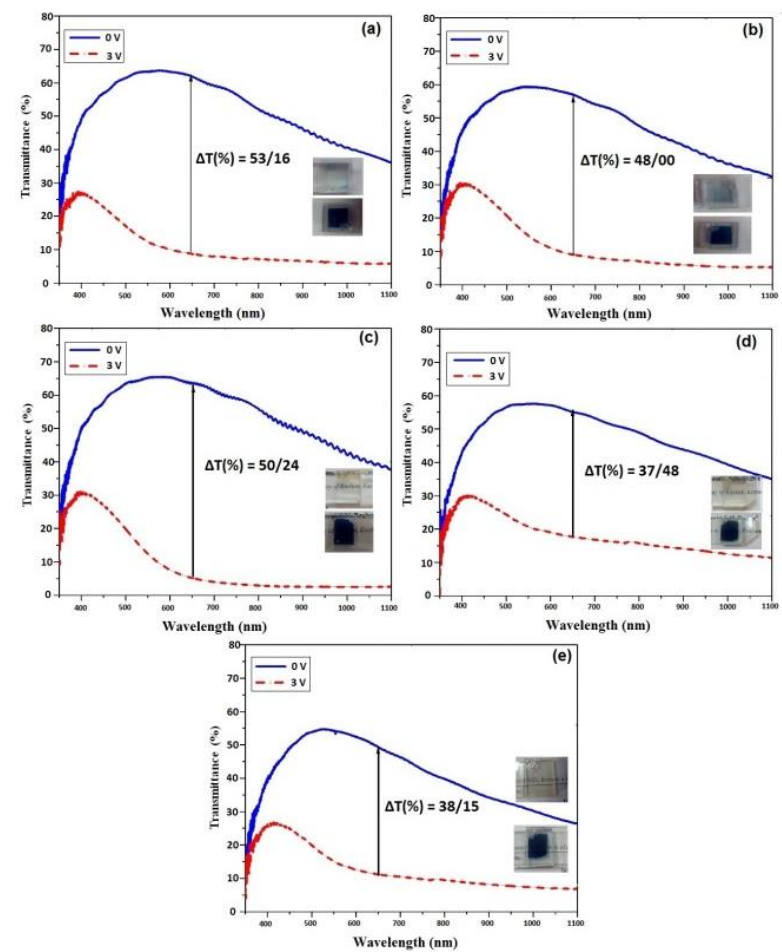

Fig. 5. Transmission spectra of the $\mathrm{WO}_{3}$ electrochromic cells prepared at various speeds of (a) $3500 \mathrm{rpm}$, (b) $3000 \mathrm{rpm}$, (c) $2500 \mathrm{rpm}$, (d) 2000 rpm and (e) 1500. rpm.

The coloration efficiency (also referred to as electrochromic efficiency) is a practical tool to measure the power requirements of an electrochromic material. In essence, it determines the amount of optical density 
change $(\Delta \mathrm{OD})$ induced as a function of the injected/ejected electron charge $Q_{d}$, i.e., the amount of charge necessary to produce the optical change. The coloration efficiency (CE) at a given wavelength is the variation of the optical density $(\Delta \mathrm{OD})$ for the charge $(\mathrm{q})$ applied per unit of the electrode area (A). It is given by the following equation:

$\eta=\frac{\Delta \mathrm{OD}}{Q_{d}}=\log \frac{\left[T_{b} / T_{c}\right]}{Q_{d}}$

where $\eta\left(\mathrm{cm}^{2} / \mathrm{C}^{-1}\right)$ is the coloration efficiency at a given $\lambda$, and $T_{b}$ and $T_{c}$ are the bleached and colored transmittance values respectively [37]. In fact, $Q_{d}$ the same area is under the color chart of the film, which is measured by an oscilloscope. On the other hand, the response time ( $T_{a}$ and $T_{b}$ ) is calculated using the same oscilloscope and calculations in Excel software. Five films with different speeds are chosen to further investigate the effect on their electrochromic performance. Table 2 lists the coloration efficiencies and the transmission modulations of five spin-coated films along with the calculated errors.

Table 2. Styles of different parts of the manuscript

\begin{tabular}{|c|c|c|c|c|}
\hline $\begin{array}{c}\text { Deposition } \\
\text { speed of } \\
\text { the film } \\
(\mathrm{rpm})\end{array}$ & $\begin{array}{c}\text { Transmission } \\
\text { modulaton } \\
\Delta \mathrm{T} 650(\%)\end{array}$ & $\begin{array}{c}\text { Optical } \\
\text { density } \\
(\Delta \mathrm{OD})\end{array}$ & $\begin{array}{c}\text { Charge } \\
\text { intercalated } \\
\mathrm{Q}_{\mathrm{d}}(\mathrm{C})\end{array}$ & $\begin{array}{c}\text { coloration } \\
\text { efficiency } \\
\eta\left(\mathrm{cm}^{2} / \mathrm{C}^{-1}\right)\end{array}$ \\
\hline \hline $1500 \pm 30$ & $38.1 \pm 0.1 \%$ & $0.6 \pm 0.02$ & $3.5 \pm 0.1$ & $179.2 \pm 0.2$ \\
\hline $2000 \pm 40$ & $37.4 \pm 0.1 \%$ & $0.4 \pm 0.02$ & $5.1 \pm 0.1$ & $99.1 \pm 0.2$ \\
\hline $2500 \pm 50$ & $50.2 \pm 0.1 \%$ & $0.7 \pm 0.02$ & $4.1 \pm 0.1$ & $194.1 \pm 0.1$ \\
\hline $3000 \pm 60$ & $48.0 \pm 0.1 \%$ & $0.8 \pm 0.02$ & $2.7 \pm 0.1$ & $294.2 \pm 0.2$ \\
\hline $3500 \pm 70$ & $53.16 \pm 0.1 \%$ & $0.8 \pm 0.02$ & $2.9 \pm 0.1$ & $295.3 \pm 0.2$ \\
\hline \hline
\end{tabular}

The coloration efficiency for the ECD device made at the speed of $1500 \mathrm{rpm}$ is found to be $197.2 \mathrm{~cm}^{2} / \mathrm{C}^{-1}$, and it increases to 295.3 $\mathrm{cm}^{2} / \mathrm{C}^{-1}$ for the ECD device made at the speed of $3500 \mathrm{rpm}$. These values are compatible with and even much more than those for tungsten oxide films reported in the literature [38, 39]. Generally, an increase in the deposition speed leads to a decrease in the layer thickness, and, as a result, a significant decrease occurs in the coloration efficiency. The best efficiency value is found to be $295.3 \mathrm{~cm}^{2} / \mathrm{C}^{-1}$ for the film deposited at the speed of $3500 \mathrm{rpm}$.

Table 3. Response time of spin-coated $\mathrm{WO}_{3}$ films along with the calculated error

\begin{tabular}{|c|c|c|}
\hline $\begin{array}{c}\text { Deposition speed } \\
\text { of the film } \\
(\mathrm{rpm})\end{array}$ & $\begin{array}{c}\text { Coloration } \\
\text { time } \\
\mathrm{t}_{\mathrm{c}}(\mathrm{s})\end{array}$ & $\begin{array}{c}\text { Bleaching } \\
\text { Time } \\
\mathrm{t}_{\mathrm{b}}(\mathrm{s})\end{array}$ \\
\hline \hline $1500 \pm 30$ & $11.1 \pm 0.1$ & $12.8 \pm 0.1$ \\
\hline $2000 \pm 40$ & $11.4 \pm 0.2$ & $12.6 \pm 0.2$ \\
\hline $2500 \pm 50$ & $13.1 \pm 0.1$ & $11.1 \pm 0.1$ \\
\hline $3000 \pm 60$ & $6.5 \pm 0.2$ & $5.5 \pm 0.2$ \\
\hline $3500 \pm 70$ & $6.9 \pm 0.1$ & $5.2 \pm 0.1$ \\
\hline \hline
\end{tabular}

EC response time is another important parameter in evaluation of electrochemical cells. Switching speed is often reported as the time required for the coloring/bleaching process of an EC material. It is important especially for applications such as dynamic displays and switchable mirrors. Table 3 provides a summary of coloration-bleaching response times along with the calculated error for five ECD devices. These response times are noticeably shorter than those for the electrochromic films reported in the literature. It has been well proved that films deposited at higher speeds have faster responses due to their larger uniform surface areas. So, this kind of structure is very good for diffusion of ions into materials, which decreases the response time.

One of the benefits of using an electrochromic material in a display, as opposed to a lightemitting material, is its optical memory (also called open-circuit memory). A memory effect refers to a situation where the optical properties remain the same for extended periods of time without a charge insertion from the drive circuit [40]. The term "memory effect" is used to describe the ability of an ECD to retain the set state of its color after the voltage is removed from the device. We kept the ECD in a colored state without an external voltage and then recorded the change of its transmittance.

The curve in Fig. 6 shows the relationship between relative transmittance and time. It is understood from the curve that, as the time 
passes, the relative transmittance is increased at the wavelength of $650 \mathrm{~nm}$ for all the cells. The longest memory, which is found to be about ten days, belongs to a film deposited at the speed of $3500 \mathrm{rpm}$. This result indicates that the ECD device developed in this study has a good memory function.

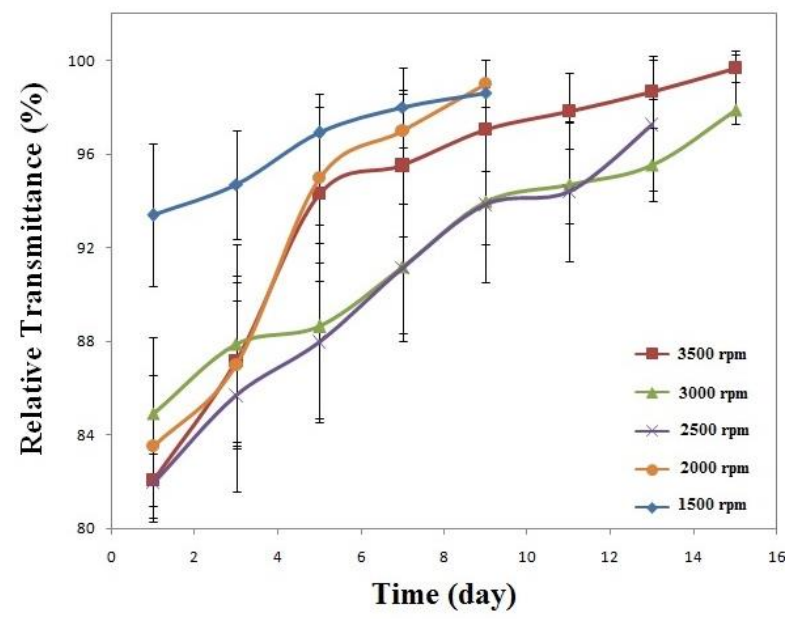

Fig. 6. The diagram of the open-circuit memory of the electrochromic cells at $\lambda=650 \mathrm{~nm}$ with error bars.

\section{CONCLUSION}

In this paper, the role of tungsten oxide $\left(\mathrm{WO}_{3}\right)$ is discussed in fabricating electrochromic films and modulating electrochromic properties. Tungsten oxide films were prepared by sol-gel and spin-coating methods using PTA as the precursor sol. X-ray analysis revealed the amorphous nature of the films for all the investigated speeds. The results indicated the structure of $\mathrm{WO}_{3}$ films annealed at $100{ }^{\circ} \mathrm{C}$ result in better electrochromic properties. Thus, heat treatment is focused on $100{ }^{\circ} \mathrm{C}$, at which amorphous tungsten oxide films can be obtained. Also, a comparison was made of the electrochromic properties of the tungsten oxide films obtained by spin-coating at various speeds and annealed at $100{ }^{\circ} \mathrm{C}$. Not only the transmittance modulation but also the coloration efficiency and the response time were improved by an increase in the deposition speed of the tungsten oxide films. Extensive characterization of these films showed that their better electrochromic performance was correlated with their thickness and deposition speed. Indeed, a decrease in the thickness of an electrochromic layer and an increase in the deposition speed can improve its performance. Among the tungsten oxide films investigated in the present study, the film doped at the speed of $3500 \mathrm{rpm}$ exhibited the best electrochromic performance with a transmittance modulation of $53.1 \%$, high coloration efficiency of $295.3 \mathrm{~cm}^{2} / \mathrm{C}^{-1}$, fast-switching times $\left(\mathrm{T}_{\mathrm{c}}=6.9 \mathrm{~s}\right.$ and $\left.\mathrm{T}_{\mathrm{b}}=5.2 \mathrm{~s}\right)$, and a good memory effect for about ten days. Through electrochromic measurements, it was indicated that $\mathrm{WO}_{3}$ films deposited at the speed of $3500 \mathrm{rpm}$ are highly promising for application in energy-saving smart windows.

\section{REFERENCES}

[1] H. Naja and A. Bahari, "Optical structural and electrochromic behavior studies on nanocomposite thin film of aniline toluidine and $\mathrm{WO}_{3}$, , Opt. Mater. Vol. 58, pp. 210218, 2016.

[2] G.H. Shim and S.H. Foulger, "Coupling of crystalline colloidal arrays with intrinsically conductive polymers: Reflection-type electrochromic devices, Photonics Nanostruct" Fundam. Appl. Vol. 10, pp. 440-446, 2012.

[3] C.G. Granqvist, "Electrochromic for smart windows: Oxide-based thin films and devices," Thin Soild Films, Vol. 564, pp. 138, 2014.

[4] M. Kamalisarvestani, F.S. Javadi, S. Mekhilef, and R.Saidur , "Performance, materials and coating technologies of thermochromic thin films on smart windows," Renewable Sustainable Energy Rev. Vol. 26, pp. 353-364, 2013.

[5] L. Mohan, C. Anandan, and N. Rajendran, "Electrochemical behaviour and bioactivity of self-organized $\mathrm{TiO}_{2}$ nanotube arrays on Ti-6Al-4V in Hanks solution for biomedical applications," Electrochim. Acta, Vol. 155, pp. 411-420, 2015.

[6] K.C. Cheng, F.R. Chen, and J.J. Kai, "Electrochemical behaviour and bioactivity of self-organized $\mathrm{TiO}_{2}$ nanotube arrays on Ti-6Al-4V in Hanks solution for biomedical applications," Sol. Energy Mater. Sol. Cells, Vol. 90, pp.1156-1165, 2006. 
[7] D.J. Rogers, V.E. Sandana, S. Gautier, T. Moudakir, and M. Razeghi, "Core-shell $\mathrm{GaN}-\mathrm{ZnO}$ moth-eye nanostructure arrays grown on a-SiO2/Si (111) as a basis for improved InGaN-based photovoltaics and LEDs," Photonics Nanostruct. Fundam. Appl. Vol. 15, pp. 53-58, 2006.

[8] V.V. Kondalkar, R.R. Kharade, S.S. Mali, R.M. Mane, P.B. Patil, P.S. Patil, S. Choudhury, and P.N. Bhosale, "Nanobricklike $\mathrm{WO}_{3}$ thin films: Hydrothermal synthesis and electrochromic application," Superlattices Microstruct. Vol. 73, pp. 290 295, 2014.

[9] S.S. Kalagi, S.S. Mali, D.S. Dalavi, A.I. Inamdar, H. Im, and P.S. Patil, "Transmission attenuation and chromic contrast characterization of R.F. sputtered $\mathrm{WO}_{3}$ thin films for electrochromic device applications," Electrochim. Acta, Vol. 85, pp. 501-508, 2012.

[10] S.A. Agnihotry, M. Kar, and T.K. Saxena, "Towards electrochromic stability in sol gel-derived tungsten oxide films: cyclic voltammetric and spectrophotometric investigations," Sol. Cells, Vol. 90, pp. 1524, 2006.

[11]M.M. Nahass, M.M. Saadeldin, H.A Ali, and M. Zaghllol, "Electrochromic properties of amorphous and crystalline $\mathrm{WO}_{3}$ thin films prepared by thermal evaporation technique," Mater. Sci. Semicond. Process. Vol. 29, pp. 201-205, 2015.

[12]A. Mohtar, W. Kassem, M. Tabbal, and M. Roumie, "Formation of $\mathrm{WO}_{3}$ by remote plasma assisted oxidation of tungsten thin films," Surf. Coatings Technol. Vol. 307, pp. 583-589, 2016.

[13]P. Madhukar, D.S. Jyothi, N. Jayababu, and M.V. Reddy, "Influence of annealing temperature on structural and dielectric properties of e-beam evaporated $\mathrm{WO}_{3}$ thin films," Mater. Today Proc. Vol. 3, pp.41994204, 2016.

[14]S. Adhikari and D. Sarkar, "Electrochimica Acta High Efficient Electrochromic $\mathrm{WO}_{3}$ Nanofibers," Electrochim. Acta, Vol. 138, pp. 115-123, 2014.

[15]V.R. Buch, A. Kumar, and S.K. Rawal, "Review on electrochromic property for $\mathrm{WO}_{3}$ thin films usingdifferent deposition techniques," Mater. Today Proc. Vol. 3, pp. 1429-1437, 2016.

[16]S. Hassab and J. Padilla, "Electrochemistry Communications Using $\mathrm{WO}_{3}$ as a transparent, optically passive counter electrode in an unbalanced electrochromic configuration," Electrochem. Commun. Vol. 72, pp. 87-90, 2016.

[17]K. Paipitak, C. Kahattha, W.T echitdheera, and S. Porntheeraphat, "Influence of Ti and Zn Dopants on Structural Properties and Electrochromic Performance of Sol-Gel Derived $\mathrm{WO}_{3}$ Thin Films," Energy Procedia, Vol. 9, pp. 446-451, 2011.

[18]H.P. Quiroz, C.P. Barrera, R.R. González, and A. Dussan, "Evidence of iridescence in $\mathrm{TiO}_{2}$ nanostructures: An approximation in plane wave expansion method," Photonics Nanostruct. Fundam. Appl. Vol. 22, pp. 4650, 2016.

[19]Z. Bi, S. Zhang, X. Li, and X. Gao, "A novel nanocomposite of $\mathrm{WO}_{3}$ modified $\mathrm{Al}-$ doped $\mathrm{ZnO}$ nanowires with enhanced electrochromic performance," Mater. Lett. Vol.160, pp. 186-189, 2015.

[20]R.R. Kharade, S.S. Mali, S.P. Patil, K.R. Patil, M.G. Gang, P.S. Patil, J.H. Kim, and P.N. Bhosale, "Enhanced electrochromic coloration in $\mathrm{Ag}$ nanoparticle decorated $\mathrm{WO}_{3}$ thin films," Electrochim. Acta, Vol. 102, pp. 358-368, 2013.

[21]L.M. Bertus, C. Faure, A. Danine, C. Labrugere, G. Campet, A. Rougier, and A. Duta, "Synthesis and characterization of $\mathrm{WO}_{3}$ thin films by surfactant assisted spray pyrolysis for electrochromic applications," Mater. Chem. Phys. Vol. 140, pp. 49-59, 2013.

[22]S. Poongodi, P. Suresh, D. Mangalaraj, N. Ponpandian, P. Meena, Y. Masuda, and C. Lee, "Electrodeposition of $\mathrm{WO}_{3}$ nanostructured thin fi lms for electrochromic and H2S gas sensor applications," J. Alloys Compd. Vol.719, pp. 71-81, 2017.

[23]M.F. Kuhaili, S.M. Durrani, E.E. Khawaja, and J. Shirokoff, "Effects of preparation conditions on the optical properties of thin films of tellurium oxide," J. Phys. D, Vol. 35, pp. 910-915, 2002.

[24]A. Sezgin, R. Budako, S. Türküz, and H. Parlar, "Electrochromic properties of 
tungsten trioxide $\left(\mathrm{WO}_{3}\right)$ layers grown on ITO / glass substrates by magnetron sputtering," J. Vac. Sci. Technol. A, Vol.120, pp. 28-31, 2015.

[25]K. Paipitak, W. Techitdheera, and S. Porntheeraphat, "Characterization of Sol-gel Derived Ti-doped Tungsten Oxide Electrochromic Thin Films," Energy Procedia, Vol. 34, pp. 689-696, 2013.

[26] V. Madhavi, P. Kondaiah, O.M. Hussain, and S. Uthanna, "Structural, optical and electrochromic properties of RF magnetron sputtered $\mathrm{WO}_{3}$ thin films," Phys. B Condens. Matter. Vol. 454, pp. 141-147, 2014.

[27]D.R. Acosta, C. Magaña, F. Hernández, and J. Ortega, "Electrical, optical and electrochromic properties of $\mathrm{Ti}: \mathrm{WO}_{3}$ thin films deposited by the pulsed chemical spray technique," Thin Solid Films, Vol. 594, pp. 207-214, 2015.

[28]K. Sauvet, L. Sauques, A. Rougier, "IR electrochromic $\mathrm{WO}_{3}$ thin films: From optimization to devices," Sol. Energy Mater. Sol. Cells, Vol. 93, pp. 2045-2049, 2009.

[29]J. De, R.M. Neto, R.M. Torresi, S.I. Cordoba, and D. Torresi, "Electrochromic behavior of $\mathrm{WO}_{3}$ nanoplate thin films in acid aqueous solution and a protic ionic liquid," J. Electroanal. Chem. Vol. 765, pp. 111-117, 2016.

[30]R. Sydam, M. Deepa, S.M. Shivaprasad, and A.K. Srivastava, "A $\mathrm{WO}_{3}$-poly (butyl viologen) layer-by-layer film/ruthenium purple film based electrochromic device switching by volt application," Sol. Energy Mater. Sol. Cells, Vol. 132, pp. 148-161, 2015.

[31]N. Mendoza, F. Paraguay, L. Hechavarría, M.E. Nicho, and H. Hu, "Nanostructured polyethylene glycol-titanium oxide composites as solvent-free viscous electrolytes for electrochromic devices," Sol. Energy Mater. Sol. Cells, Vol. 95, pp. 2478-2484, 2011.

[32]C. Sella, M. Maaza, O. Nemraoui, J. Lafait, N. Renard, and Y. Sampeur, "Preparation, characterization and properties of sputtered electrochromic and thermochromic devices," Surf. Coatings Technol. Vol. 98, pp. 1477-1482, 1998.

[33]E. Ienei, A.C. Milea, and A. Duta, "Influence of spray pyrolysis deposition parameters on the optical properties of porous alumina films," Energy Procedia, Vol. 48, pp. 97-104, 2014.

[34]Y.S. Krasnov, S.V. Volkov, and G.Y. Kolbasov, "Optical and kinetic properties of cathodically deposited amorphous tungsten oxide films," J. Non. Cryst. Solids. Vol. 352, pp. 3995-4002, (2006).

[35]A. Karuppasamy and A. Subrahmanyam, "Studies on electrochromic smart windows based on titanium doped $\mathrm{WO}_{3}$ thin films," Thin Solid Films, Vol. 516, pp.175-178, 2007.

[36]B. Baloukas, J.M. Lamarre, and L. Martinu, "Electrochromic interference filters fabricated from dense and porous tungsten oxide films," Sol. Energy Mater. Sol. Cells, Vol. 95, pp. 807-815, 2011.

[37]H. Sadiki, J.F. Pierson, C. Rousselot, N. Martin, and G. Terwagne, "Properties and electrochromic performances of reactively sputtered tungsten oxide films with water as reactive gas," Surf. Coatings Technol. Vol. 200, pp. 232-235, 2005.

[38]N. Naseri, R. Azimirad, O. Akhavan, and A.Z. Moshfegh, "Improved electrochromical properties of sol-gel $\mathrm{WO}_{3}$ thin films by deposited gold nanocrystals," Thin Solid Films, Vol. 518, pp. 2250-2257, 2010.

[39]J.M. León, D.R. Acosta, U. Pal, and L. Castañeda, "Improving electrochromic behavior of spray pyrolised $\mathrm{WO}_{3}$ thin solid films by Mo doping," Electrochim. Acta, Vol. 56, pp. 2599-2605, 2011.

[40]K.J. Patel, C.J. Panchal, M.S. Desai, and P.K. Mehta, "An investigation of the insertion of the cations $\mathrm{H}+, \mathrm{Na}+, \mathrm{K}+$ on the electrochromic properties of the thermally evaporated $\mathrm{WO}_{3}$ thin films grown at different substrate temperatures," Mater. Chem. Phys. Vol. 124, pp. 884-890, 2010. 


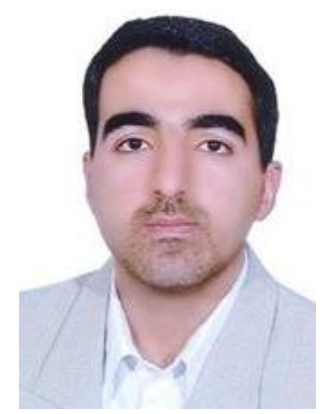

Seyed Mohamad Bagher Ghorashi was born in Shahreza, Iran, in 1978. He received the B.E. degree in Physics from the Yazd University, in 2000, and the M.Sc. degree from Isfahan University, in 2004, and $\mathrm{PhD}$ degree from the Yazd University in 2011.

In 2011, he joined the Department of Physics, University of Kashan, as an Assistant Professor. His current research interests include Organic and Polymer Solar Cells, Perovskite Solar Cells, Thin Films, SIGS Solar Cells, Electrochromic Glasses and OLED.

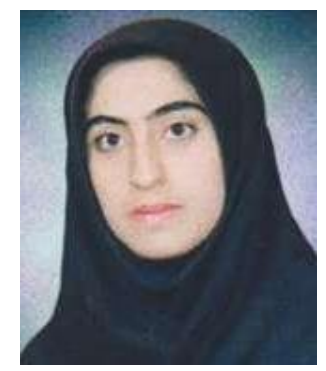

Nayereh Daroogheh was born in Kashan, Iran. She received her B.Sc. in applied physics from the University of Kashan, in 2012. She received her M.Sc. in Optics and Laser from the University of Kashan, in 2015.

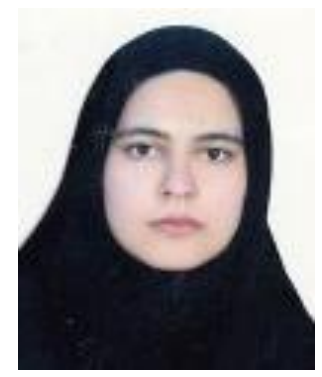

Elham Karimi was born in Isfahan, Iran. She received her B.Sc. from Kharazmi University, Iran in 2011. She received her Master's degree from Isfahan University, Iran in 2013. Currently, she is a $\mathrm{PhD}$ candidate in Optics and Laser in the University of Kashan, Iran. Her research interest focuses on investigation on perovskite solar cells and organic solar cells. 